\title{
Qual o âmbito do Direito Internacio- nal Penal, aludido no art. 81, letra h, da Constituição Federal?
}

(Ponto número 4)

\section{Noé Azevedo}

A Constituição de 1934 veiu renovar a célebre discussão que suscitara, tanto na doutrina como na jurisprudência, o dispositivo da nossa lei fundamental de 1891. Esta preceituava no art. 60, letra $h$ :

"Compete aos juizes ou tribunais federais processar e julgar:

h) as questões de direito criminal ou civil internacional".

A reforma de 1926 suprimiu êsse inciso, fazendo assim desaparecer a controvérsia. Essas questões passaram, de então em diante, a ser havidas como da competência da justiça local, na esfera do direito civil internacional, sem mais polêmicas. As questões frequentes em nossos tribunais são as de direito civil internacional, e não as de direito penal internacional. Por isso, entendemos, não surgiram dificuldades. Entretanto, devemos observar que a reforma de 1926, cortando as dúvidas sôbre o conceito de "questões de direito internacional", não dirimiu as dificuIdades no que respeita 
a "questões de direito penal internacional" Não surgiram casos para serem resolvidos. Mas se tais casos tivessem aparecido, no interregno de 1926 a 1934, não sabemos como se haveriam os nossos tribunais ou juizes. Aparecesse um caso de direito penal internacional, um crime internacional para julgamento, e ficaríamos sem saber onde ajuizá-lo. A matéria de competência é stricti juris. Não pode ser atribuida por analogia. Suprimindo o inciso da letra $h$ do art. 60 da Constituição de 1891, não determinou o Constituinte de 1926 quais as autoridades judiciárias competentes para o julgamento dêsses crimes, que não desapareceram dos textos de direito internacional nem dos próprios textos das nossas leis territor iais. Entendemos, por isso, ter havido extraordinária argúcia no exemplo de crime capaz de suscitar questão de direito internacional, que foi citado pelo grande Pedro LEssa ao fixar o entendimento daquela disposição constitucional de 1891. Sustentava êle que, para evitar dificuldades, sempre que surgisse uma questão em que as partes fossem estrangeiras, devia-se processar na justiça federal, sem se aguardar o levantamento de "questão" ou controvérsia sôbre a aplicação do direito internacional. E citava a hipótese de um crime cometido em nosso paiz pelo fâmulo de uma legação ou embaixada. Enquanto não surgisse reclamação do representante diplomático, seria indiferente que o processo se fizesse quer perante a justiça local, quer perante a federal. Pelos princípios, ou costumes de direito internacional até então vigentes, êsses crimes poderiam ser processados nos paises onde estivessem acreditados os representantes diplomáticos, desde que êstes não reclamassem no sentido do julgamento ser feito no seu país.

Êsse exemplo mostra que a reforma de 1926, cortando a dúvida quanto às questões de direito civil, criou maior dificuldade quanto às questões de direito penal. Deixou-as, mesmo, insolúveis.

Com efeito, qual seria nesse regime o juiz competente para o processo de um empregado brasileiro de uma legação do Brasil, que cometesse crime no estrangeiro, e que devesse 
ser julgado no Brasil em virtude de reclamação do nosso agente diplomático, que notasse grande exaltação de ânimo da parte da população do país, deixando sem as necessárias garantias o nosso patrício? E se em vez de ser um simples criado, fosse o criminoso um secretário de legação ou um outro funcionário de categoria inferior, mas que houvesse praticado o crime para desafrontar os brios nacionais de certas injúrias muito comuns no estrangeiro aos nossos fóros de país civilizado? Ėsse nosso patrício não poderia ficar ao desamparo, sujeito ao ódio de tribunais populares estrangeiros. $\mathrm{O}$ direito internacional reconhece, invariavelmente, aos representantes diplomáticos o direito de reclamar que o julgamento em tais casos seja feito no seu país. Entretanto, não teríamos aquí, em face da Constituição de 1926, uma competência judicial definida para o julgamento de tais crimes. Aí está, portanto, a demonstração de que era necessário o restabelecimento do preceito da célebre letra $h$, na parte relativa ao direito penal.

Não poderíamos deixar os nossos patrícios, que por motivos patrióticos pudessem cometer crimes no estrangeiro, inteiramente desamparados, privados de uma garantia de julgamento pelos seus concidadãos. Mas não teríamos aquí uma norma precisa para determinar qual o juizo competente para o seu julgamento. A regra geral é a que dá competência ao fôro do delito. Mas o delito não foi cometido no país! Onde ajuizar o processo?

Pela Constituição de 1926, ou deixávamos êsse funcionário de legação sujeito aos tribunais estrangeiros, ou reclamávamos o seu julgamento aquí, mas neste caso não saberíamos onde, nem perante qual das justiças ajuizar a causa. Agora, em face da disposição do art. 81, letra $h$, já sabemos que a justiça competente é a federal. Trata-se evidentemente de um caso de direito penal internacional. Temos aí uma derrogação da regra geral da territorialidade da lei penal, derrogação estabelecida a princípio pelos costumes internacionais, e hoje consagrada em textos especiais de leis internas, como a lei processual alemã e a do Estado de Nova 
York, segundo citação de Florian, e também regulada pelo Código Bustamante.

0 art. 76, letra $b$, da atual Constituição dá competência à Côrte Suprema para processar e julgar originariamente "os embaixadores e ministros diplomáticos, nos crimes comuns e nos de responsabilidade" Não declara, entretanto, quais os juizes competentes, dentro do quadro da justiça federal, para processar e julgar os funcionários e empregados de embaixada. Deixa isso, naturalmente, a cargo do legislador ordinário.

Justificando assim a necessidade do dispositivo do artigo 81 , letra $h$, na parte relativa às questões de direito penal internacional, vejamos agora qual o âmbito dêsse direito. Ele não envolve somente os crimes dos agentes diplomáticos e dos funcionários e empregados de embaixadas. Compreende os crimes internacionais propriamente ditos, os crimes dos agentes diplomáticos, funcionários e empregados de legações, e também os crimes comuns cuja punição não interessa aos Estados em que são praticados, interessando todavia a determinados paises em cujo prejuizo foram perpetrados. Vejamos em primeiro lugar os crimes internacionais.

A noção de crime internacional ainda não se acha definitivamente assente em doutrina. Dêsse assunto têm tratado com muita erudição, entre outros, os professores QuiNtiliano Saldaña e Vespasiano Pella. Aquele nas suas conferências na Academia de Direito Internacional de Haia, resumidas no opúsculo "La Defensa Social Internacional", e êste no projeto de organização da Justiça Internacional. Distinguem a criminalidade dos Estados - considerados como sujeitos de crimes pela violação das leis internacionais - da criminalidade internacional dos indivíduos. A primeira ficaria sujeíta, e já está em grande parte sujeita, aos tribunais internacionais: Tribunal de Justiça Internacional de Haia - Consêlho da Liga das Nações, etc. A criminalidade internacional dos indivíduos será reprimida pelos próprios tribunais dos diferentes paises. $\mathrm{E}$ tem ha- 
vido grande trabalho no sentido de facilitar essa repressão, como se pode ver dos estudos dos professores citados, das conferências de J. A. Roux na Academia de Haia, publicadas no "Recueil des Cours" de Sirey, e ainda das atas da conferência internacional para unificação do Direito Penal, promovida pelo instituto de Genebra.

Quintiliano Saldaña, na obra já referida, e no programa do curso que professou em Haia, faz enumeração detalhada dos chamados crimes internacionais. Dêstes crimes há alguns que são cometidos fora do território dos Estados e outros que são praticados internacionalmente, extendendo-se ao território de mais de um Estado, prolongando-se até de um continente a outro. O Código Bustamante prevê crimes dessas duas modalidades, estabelecendo a competência para o respectivo julgamento. Sob a epígrafe “Dos Delitos Cometidos fóra do Território Nacional" enumera, no art. 308:

"A pirataria, o tráfico de negros e o comércio de escravos, o tráfico de mulheres brancas, a destruição ou deterioração de cabos submarinos" E determina que êsses e os demais delitos da mesma índole, contra o direito internacional, cometidos no alto mar, no ar livre e em territórios não organizados ainda em Estado, serão punidos pelo captor, de acôrdo com as suas leis penais.

Sob a epígrafe "Dos delitos cometidos em um Estado Estrangeiro contratante", dispõe o art. 307 desse Código que - "Também estarão sujeitos às leis penais do Estado estrangeiro em que possam ser detidos e julgados aqueles que cometam fora do território um delito, como o tráfico de mulheres brancas, que êsse Estado contratante se tenha obrigado a reprimir por acôrdo internacional"

Aí estão varias hipóteses de crimes internacionais que podem ser punidos no Brasil, uns praticados em alto mar ou alto ar e outros fora do território nacional, ou parte fora e parte aquí, como o tráfico de mulheres brancas, que nos obrigamos a reprimir pela convenção de Paris de 1902, 
e que devem ser processados perante a justiça federal por fôrça do preceito da letra $h$ do art. 81 .

Quanto aos crimes cometidos no estrangeiro contra interesses nacionais, também êles constituem questões de direito internacional. Em geral são concordantes as leis dos diferentes paises civilizados quanto às derrogações do princípio da territorialidade das leis penais, havendo divergência às vezes em questões de detalhes, como entre a nossa lei e a francesa no que se refere a crimes em navios mercantes em porto estrangeiro. Não surgirão por isso os conflitos de leis tão comuns em matéria civil, e que constituem o objeto principal do Direito Civil Internacional, denominado pelos ingleses e americanos "Conflict of Laws" Mas, apesar de não surgirem questões propriamente ditas, ou disputa quanto à lei a aplicar-se visto haver concordância entre as diversas leis no estabelecerem em geral as mesmas derrogações, não deixaremos de ter casos de competência da justiça federal, pois, em muitos deles, surgirão até questões de Direito Internacional Público. Nas questões referentes a crimes contra os interesses nacionais cometidos no estrangeiro, parece indubitável a competência da justiça federal. A maior parte dêsses crimes será contra o interesse direto da União, justificando-se por isso a competência federal por fôrça do art. 81, letra $a$, da Constituição, e outras leis federais, como o decreto n. 4.780, ao estabelecer a competência para o julgamento dos crimes nele previstos, e principalmente $e x$ vi do art. 81, letra $i$, da Constituição, que dá competência à justiça federal para o processo e julgamento dos crimes praticados em prejuizo de serviços e interesses da União. Mas ainda nos casos em que os crimes praticados no estrangeiro não afetem diretamente interesse da União, a competência deve ser da justiça federal, como nos casos de falsificação de papéis de crédito dos Estados e dos Bancos (Consolidação, arts. 5, n. ${ }^{\circ}$ II, letra $d$, e arts. 246 a 250). Pensamos que, mesmo na hipótese destes crimes serem praticados no estrangeiro contra interesses dos Estados ou dos Bancos e não da União direta- 
mente, a competência é da justiça federal, porque em quasi todos poderão ser suscitadas questões de direito internacional, como as que são aventadas pelo próprio art. $5, \S 2 .^{\circ}$, da Consolidação das Leis Penais. Mas, ainda que tais questões não surgissem, não teríamos elementos para ajuizar êsses crimes perante as justiças dos Estados, porquê o fôro competente nessas justiças é determinado pelo lugar do delito, e sendo êste praticado fora da República, e portanto fora das respectivas circunscrições estaduais, não saberíamos onde ajuizá-los.

Bastaria, entretanto, a possibilidade e possibilidade muito provável de surgir questão de direito internacional, para legitimar a competência federal em semelhantes hipóteses. Dir-se-á que não há inconveniente algum em ajuizar-se um caso dêsses perante a justiça local, pois hoje temos o preceito salutar do art. 71 da Constituição de 1934, segundo o qual "a incompetência da justiça federal ou local, para conhecer do feito, não determinará a nulidade dos atos processuais probatórios e ordinatórios, desde que a parte não a tenha arguido", acrescentando que "reconhecida a incompetência, serão os autos remetidos ao juizo competente, onde prosseguirá o processo" Êsse preceito, porém, fazendo depender a validade dos atos praticados da aquiescência da parte, somente poderá ter aplicação quando se tratar de assunto em que possa ter lugar alguma convenção particular, isto é, quando o pacto dos particulares possa derrogar as disposições legais. Sendo a competência em materia penal ditada por disposições de ordem pública, duvidamos da aplicabilidade do preceito do art. 71 nessa matéria. Resumindo, diremos que são questões de direito internacional penal as que surgem:

$\left.1 .^{\circ}\right)$ Dos chamados crimes internacionais que a doutrina vem definindo, e dos quais trata o Código Bustamante nas disposições citadas; 
$2 .{ }^{\circ}$ ) Dos crimes praticados no estrangeiro por agentes diplomáticos brasileiros, funcionários e empregados de embaixadas e legações, que gosam de prerrogativa quanto à justiça, de acôrdo com os costumes internacionais;

$3 .^{\circ}$ ) Dos crimes cometidos no estrangeiro contra interesses nacionais diretos ou indiretos, conforme a prescrição do art. $5 .^{\circ}$ da Consolidação das Leis Penais (os crimes contra a nação e os políticos estão sujeitos a disposições especiais).

São Paulo, 5 de outubro de 1936. 